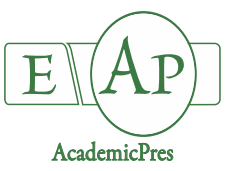

Curiel-Maciel NF et al. (2021)

Notulae Botanicae Horti Agrobotanici Cluj-Napoca

Volume 49, Issue 2, Article number 12021

DOI: $10.15835 /$ nbha 49212021

Research Article

\title{
Nutritional quality, fatty acids content and antioxidant capacity of pecan nut fruits from Criolla and Improved walnut varieties
}

\author{
Nidya F. CURIEL-MACIEL ${ }^{1}$, Jesús G. ARREOLA-ÁVILA², Juan R. \\ ESPARZA-RIVERA ${ }^{3}$, Edén A. LUNA-ZAPIÉN ${ }^{2}$, José R. MINJARES- \\ FUENTES ${ }^{3}$, Erick SIERRA-CAMPOS ${ }^{3}$, Jorge A. MEZA-VELÁZQUEZ ${ }^{3 *}$
}

\author{
${ }^{1}$ Universidad Autónoma del Estado de Morelos, Centro de Investigación en Biotecnología, Av. Universidad No. 1001, Col. \\ Chamilpa, C.P. 62209, Cuernavaca, Morelos, México; nidyacm@gmail.com \\ ${ }^{2}$ Universidad Autónoma Chapingo Unidad Regional Universitaria de Zonas Áridas, Carretera Gómez Palacio - Ciudad Juárez, \\ Bermejillo km 40, C.P.35230,Dgo, México; arreolavila@gmail.com; luna_141110@hotmail.com \\ ${ }^{3}$ Universidad Juárez del Estado de Durango, Facultad de Ciencias Químicas, Av. Articulo $123 \mathrm{~s} / \mathrm{n}$ Fraccionamiento Filadelfia, C.P. \\ 35010,GómezPalacio,Dgo, México; jresparza02001@yahoo.com; rafaelminjares@gmail.com; ricksier@gmail.com; \\ jorgemezav68@gmail.com ("correspondingauthor)
}

\begin{abstract}
In the current study were evaluated the nutrimental quality, fatty acid and mineral content, and antioxidant capacity of pecan nut of Criolla and Improved walnut varieties. Nut fruit samples of three Criolla walnut varieties ('Nazas I', 'Nazas II' and 'Norteña'), and two Improved varieties ('Western' and 'Wichita') were collected in La Laguna (Nazas, Durango) in Northern Mexico. The analyses run in nut samples were: bromatological and mineral content, fatty acids profile and antioxidant capacity. The results showed that Criolla and Improved varieties had similar bromatological content except 'Nazas I', which had the lowest protein and fat content. Furthermore, nuts from Criolla varieties had a higher mineral content, including iron $(\sim 38 \mathrm{mg} / 100 \mathrm{~g} \mathrm{dw})$, zinc $(\sim 51 \mathrm{mg} / 100 \mathrm{~g} \mathrm{dw})$ and manganese $(25 \mathrm{mg} / 100 \mathrm{~g} \mathrm{dw})$. Besides, the fatty acid profile indicates a higher rate of oleic acid $(71 \%)$ in nut oil of Criolla varieties than in Improved varieties (61\%). Regarding antioxidant capacity $(\mathrm{AC})$ the obtained values were similar in all varieties, with 'Norteña' variety ( $850 \mu \mathrm{M}$ trolox equivalent/g of oil) in Criolla, and 'Western' ( $800 \mu \mathrm{M}$ trolox equivalent/g of oil) in Improved as the highest values of $\mathrm{AC}$ among all varieties. Hence, pecan nut fruits of Criolla varieties are good nutrients and beneficial health compounds source for consumers, and their production and marketing represent interesting opportunity areas for nut producers.
\end{abstract}

Keywords: health benefits; nut; nutriments; oleic acid

\section{Introduction}

Pecan walnut [Carya illinoinensis (Wangenh.) K. Koch] is a native tree from northern Mexico and southern U.S. (Su et al., 2004; Beuchat and Pegg, 2013), although is also cultivated in other regions like Australia, South Africa, Israel and South America (Wakeling et al., 2001). Walnut tree is considered as one of the most important species among the Carya gender. Nut is the fruit obtained from this tree, and one of its

Received: 03 Aug 2020. Received in revised form: O7 Apr 2021. Accepted: 27 Apr 2021. Published online: 11 May 2021.

From Volume 49, Issue 1, 2021, Notulae Botanicae Horti Agrobotanici Cluj-Napoca journal uses article numbers in place of the traditional method of continuous pagination through the volume. The journal will continue to appear quarterly, as before, with four annual numbers. 
main attributes is its high oil content that can be up to $75 \%$ depending on growth conditions, maturity and variety nut (Wakeling et al., 2001). Nut oil is mostly composed by unsaturated fatty acids such as oleic (60$70 \%$ ) and linoleic acid (up to30\%), and very low amounts of others fatty acids including palmitic, stearic and linoleic acids (Beuchat and Worthington, 1978; Santerre, 1994). Hence, nut fruit can be an important antioxidant supply to diet due to its unsaturated fatty acids (Senter and Horvat, 1978) and tocopherol content (Domínguez-Avila et al., 2013; Nishi et al., 2014), and its regular consumption can help to prevent chronic degenerative diseases associated to lipids consumption (Dominguez-Avila et al., 2015).

México is the fifth pecan nut world producer, with a walnut cultivated surface of 110, 530.82 ha, and an annual production of 147,198 ton of nut (SIAP-SAGARPA, 2018). However, most of the world market is composed by Improved varieties, which result from either grafts or genetic cross of selected varieties of a high quality and yielding features (Thompson and Grauke, 2012). Besides, yielding, and oil and sensorial quality of nut fruits from these modified (or 'Improved') walnut varieties can be affected by pests and diseases as well as by climatic conditions during its production cycle (Aguilar Perez et al., 2015). One of the alternatives to decrease such undesired effects in nut fruit quality and yielding are to search 'criollo' nut genotypes.

In Mexico there are several native genotypes classified as Criolla varieties, which have an early maturation and are resistant to infectious diseases like villus stain (Mycosphaerella caryigena) and roña, a micotic disease caused by Cladosporium carygenum (Aguilar Perez et al., 2015). Criolla nut genotypes are those varieties resulting from ungrafted trees, and regularly are either medium or small size fruits, with a thick and hard-shell nut, and highly adapted to a delimited region, thereby resulting an interesting alternative for nut producers. Furthermore, there are also Criolla nut varieties with a high nutritional quality fruit mostly due to its unsaturated fatty acids content (Wakeling et al., 2001), in addition to its mineral and vitamin content (Martínez-Peniche, 2001). Hence, such Criolla varieties can be an interesting production alternative for nut fruit production due to its lower production cost and better adaptation to different production conditions (Grauke, 1988).

The aim of this study was to determine bromatological composition, fatty acid profile and content and antioxidant capacity of nut fruit from Criolla and Improved varieties cultivated in La Laguna, Durango (Mexico).

\section{Materials and Methods}

Vegetable samples

The pecan nut fruits evaluated in this study were selected genotypes from three Criolla nut varieties ('Nazas I', 'Nazas II' and 'Norteña'), and two Improved varieties ('Western' and 'Wichita'). Five kg of nut fruit of each variety were collected from walnut trees cultivated in La Laguna (Durango), located in northern Mexico. Selected walnut trees were 18-year-old with a similar irrigation and fertilization conditions. Sample collection was performed in Nazas, Durango, located at $25^{\circ} 23^{\prime}$ north latitude and $104^{\circ} 3^{\prime}$ west longitude, with an altitude of 1250 masl, dry climate, and an annual average temperature of $20.8^{\circ} \mathrm{C}$.

\section{Reagents}

HPLC grade solvents (chloroform, methanol, hexane, and water); hydrochloric and nitric acid; sodium sulphate and hydroxide, boron trifluoride, fatty acids mixture standard; and elements standard trace grade (calcium, cupper, iron, manganese and zinc) were all acquired from Sigma-Aldrich.

\section{Bromatological analyses}

Analytical tests were performed according to AOAC methods (Horwitz, 2010) of protein (950.48), fat (948.22), ashes (920.48), crude fiber (985.29), humidity (930.15) content, and total carbohydrates by weight difference. 


\section{Oil extraction}

Oil nut was extracted using an adaptation of Bligh and Dyer method (1959). Approximately $8 \mathrm{~g}$ of grounded nut almond simple were placed in $50 \mathrm{~mL}$ plastic tubes, and mixed with $30 \mathrm{~mL}$ of a chloroformmethanol-water $(1: 2: 2 \mathrm{v} / \mathrm{v})$ solution. The blend was vortexed for $2 \mathrm{~min}$ and left without agitation for 20 more min. Afterwards the blend was centrifuged (Centurión Pro-Research, UK) at $3000 \mathrm{rpm}$ for $5 \mathrm{~min}$ at $20^{\circ} \mathrm{C}$, and the lipidic (chloroform-oil) phase was extracted and dehydrated in sodium sulphate. The samples residues were removed from the sodium sulphate by washing it twice with chloroform, and finally the remaining solvent was removed in a rotavapor at $65 \mathrm{~mm}$ de $\mathrm{Hg}$ and $40{ }^{\circ} \mathrm{C}$. The obtained oil sample was stored at $5^{\circ} \mathrm{C}$ until further analyses ( $\leq 6$ days).

\section{Fatty acids methylated esters extraction}

Fatty acids methylated esters (FAME) extract was obtained using the AOAC method 969.33 (Horwitz, 2010). Approximately $0.5 \mathrm{~g}$ of oil sample and $1 \mathrm{~mL}$ of $1 \mathrm{~N} \mathrm{NaOH}$ in methanol were mixed. The mixture was vigorously agitated and heated under boiling bath for $15 \mathrm{~min}$, and cooled at room temperature. Afterwards 1 $\mathrm{mL}$ of $14 \%$ boron trifluoride was added and the mixture was vortexed for $2 \mathrm{~min}$ and allowed to rest without agitation for 30 more min. Then, $2 \mathrm{~mL}$ of hexane and $1 \mathrm{~mL}$ of distilled water were added, and the mixture was vortexed for $1 \mathrm{~min}$ and centrifuged at $1000 \mathrm{rpm}$ for $5 \mathrm{~min}$. The hexane (FAME) phase was extracted and made up to a $10 \mathrm{~mL}$ volume with hexane. The FAME extract was finally stored in amber vials at $-40{ }^{\circ} \mathrm{C}$ until its analyses ( $\leq 6$ days).

\section{Fatty acids identification and quantification}

One $\mu$ l of the methylated esters (FAME) extract was injected into an Agilent 6820 gas chromatograph (Agilent Technology, CA, EUA) equipped with an ionization flame detector. FAME were separated in a Supelco SP2560 capillary column (120 m x $0.25 \mathrm{~mm}$ x $0.2 \mu \mathrm{m})$ (Supelco Analytical, PA, USA) using helium as a carrier gas at a 50-psi pressure. The chromatograph operation conditions were: Injector in a splitless mode at a temperature of $260^{\circ} \mathrm{C}$, initial column temperature of $110^{\circ} \mathrm{C}$ with an increase of $5^{\circ} \mathrm{C} / \mathrm{min}$ until reaching 225 ${ }^{\circ} \mathrm{C}$ during $6 \mathrm{~min}$. High purity standards of FAME were used not only to identify but also quantify these compounds $\left(\mathrm{R}^{2} \geq 0.99\right)$. Fatty acid expressed as percentage of total fatty acid content.

\section{Mineral analyses}

The evaluated minerals were calcium, copper, iron, manganese and zinc. One gm of grounded nut almond sample was mixed with $10 \mathrm{~mL}$ of concentrated nitric acid and $7 \mathrm{~mL}$ of $7 \% \mathrm{Mg}\left(\mathrm{NO}_{3}\right)_{2}$ (digestion procedure), and dried in a stove at $90-95^{\circ} \mathrm{C}$. Afterwards the mixture was placed in a Thermolyne 48000 oven (Barnstead International, Iowa, USA) at $80^{\circ} \mathrm{C}$, and oven temperature was gradually increased $3{ }^{\circ} \mathrm{C} / \mathrm{min}$ up to $350{ }^{\circ} \mathrm{C}$, maintaining such temperature until the sample was fully burned. Then, the oven temperature was increased to $525^{\circ} \mathrm{C}$ and maintained for $16 \mathrm{~h}$, and finally the sample was allowed to cool to room temperature. The remaining sample was mixed with $2 \mathrm{~mL}$ of $50 \% \mathrm{HNO}_{3}$ and heated at $120{ }^{\circ} \mathrm{C}$ until got dried. Later, the sample was placed in the oven at $80^{\circ} \mathrm{C}$, and oven temperature was gradually increased $3{ }^{\circ} \mathrm{C} / \mathrm{min}$ until reaching $525^{\circ} \mathrm{C}$, maintaining the oven temperature for $30 \mathrm{~min}$. The remaining ashes were dissolved in $4 \mathrm{~mL}$ of $50 \%$ hydrochloric acid and made up to a $25 \mathrm{~mL}$ volume (SSA, 1994) with HPLC grade distilled water. Analyses were run using a blank (no sample), and a fortified sample, which was added with a mineral element spike during the digestion procedure. Samples were analyzed in an atomic absorption spectrophotometer Buck model 210 (Buck Scientific Inc. Norwalk, U.S.) by using the flame method. Mineral element quantification was done using standard curves with mineral element standard of calcium, iron, manganese, copper and zinc $\left(\mathrm{R}^{2} \geq 0.99\right)$. Results are presented on $\mathrm{mg} / 100$ dry weight. 


\section{Antioxidant capacity}

The antioxidant capacity was evaluated using the $\beta$-carotene-linoleic acid bleaching method following the procedure published by Duarte-Almeida et al. (2006). A stock solution was prepared mixing $2 \mathrm{mg}$ of $\beta$ carotene, $45 \mathrm{mg}$ of linoleic acid and $400 \mathrm{mg}$ of Tween $40 \mathrm{in} 10 \mathrm{~mL}$ of chloroform. Chloroform was removed using a vacuum oven, the final stock solution was prepared adding to the remaining linoleic acid- $\beta$ carotenetween mixture $100 \mathrm{~mL}$ of distilled water. A $0.5 \mathrm{~mL}$ sample of oil nut diluted in ethanol was mixed with $4.5 \mathrm{~mL}$ of final stock solution in an amber vial, and immediately was read the mixture absorbance in a spectrophotometer at a wavelength of $470 \mathrm{~nm}$ (zero time), and the mixture sample was incubated at $50{ }^{\circ} \mathrm{C}$, reading its absorbance after 2 hours. A standard curve was prepared using Trolox $\left(R^{2} \geq 0.99\right)$, and the results were reported in $\mu \mathrm{M}$ Trolox equivalent/g of oil.

\section{Statistical analysis}

Results were analyzed using a one-way ANOVA, and mean differences were found by means of the multiple comparison test of Fisher $(\mathrm{P}<0.05)$, using the SAS software version 8 (SAS Institute Inc, 2005).

\section{Results and Discussion}

\section{Bromatological quality}

Nowadays consumers demand high nutritional content food products since it is known that their consumption is related to health benefits. The bromatological analyses results of the Criolla ('Nazas I', 'Nazas II' and 'Norteña') and Improved ('Wichita' and 'Western') pecan nut varieties are shown in Table 1. Regarding fat content all nut varieties had a similar composition except the 'Nazas I', which had the lowest fat content $(\mathrm{P}<0.05)$. Besides, all nut varieties had a high protein $(7.35 \pm 0.48 \%)$ and fiber $(12.05 \pm 2.74 \%)$ content. These results are similar to those published by other researchers (Singanusong et al., 2003; Ozkan and Koyuncu, 2005), with some slight differences attributable to agricultural practices, season and geographic location (Aguilar Perez et al., 2015). Hence, these evaluated nut varieties are excellent fiber and protein source (Mudgil and Barak, 2013; Ötles and Ozgoz, 2014), and can be comparable to high nutritional quality food products like fresh eggs.

Table 1. Bromatological analyses (\%) of pecan nut fruits from Criolla and Improved varieties grown in Laguna region (Durango, Mexico)

\begin{tabular}{|c|c|c|c|c|c|c|}
\hline Variety & Humidity & Ashes & Fiber & Fat & Protein & CH $^{*}$ \\
\hline 'Nazas I' & $3.6 \pm 0.1^{\mathrm{b}}$ & $1.7 \pm 0.2^{\mathrm{a}}$ & $11.2 \pm 2.9^{\mathrm{bc}}$ & $53.8 \pm 11.6^{\mathrm{b}}$ & $5.6 \pm 0.4^{\mathrm{c}}$ & $20.9 \pm 13.4^{\mathrm{a}}$ \\
\hline 'Nazas II' & $4.2 \pm 0.1^{\mathrm{a}}$ & $1.5 \pm 0.3^{\mathrm{abc}}$ & $8.3 \pm 1.9^{\mathrm{c}}$ & $67.3 \pm 1.2^{\mathrm{a}}$ & $8.2 \pm 0.6^{\mathrm{a}}$ & $10.9 \pm 1.5^{\mathrm{b}}$ \\
\hline 'Norteña' & $3.0 \pm 0.2^{\mathrm{c}}$ & $1.3 \pm 0.1^{\mathrm{c}}$ & $10.1 \pm 1.8^{\mathrm{bc}}$ & $65.5 \pm 1.8^{\mathrm{a}}$ & $7.9 \pm 0.5^{\mathrm{ab}}$ & $11.6 \pm 3.7^{\mathrm{b}}$ \\
\hline 'Wichita' & $3.4 \pm 0.2^{\mathrm{b}}$ & $1.4 \pm 0.1^{\mathrm{bc}}$ & $16.9 \pm 4.2^{\mathrm{a}}$ & $65.4 \pm 8.5^{\mathrm{a}}$ & $7.3 \pm 0.5^{\mathrm{b}}$ & $4.9 \pm 6.7^{\mathrm{c}}$ \\
\hline 'Western' & $2.9 \pm 0.2^{\mathrm{c}}$ & $1.6 \pm 0.1^{\mathrm{ab}}$ & $13.6 \pm 2.9^{\mathrm{ab}}$ & $58.7 \pm 2.4^{\mathrm{ab}}$ & $7.7 \pm 0.4^{\mathrm{ab}}$ & $14.9 \pm 3.8^{\mathrm{ab}}$ \\
\hline
\end{tabular}

Results (\%) stand for mean \pm standard deviation $(\mathrm{n}=5)$. Different characters in the same column mean significantly different values according to Fisher test $(\mathrm{P}<0.05)$.

${ }^{*}$ Carbohydrates

\section{Mineral content}

The results of mineral content showed that iron, zinc and manganese content in nut fruits from Criolla varieties was higher than in Improved genotypes $(\mathrm{P}<0.05)$, meanwhile copper content was higher in Improved varieties. Calcium content was similar in all evaluated varieties. These results disagree with those reported by Singanusong et al. (2003), who published a higher $\mathrm{Cu}, \mathrm{Mn}$ and Ca content in other nut varieties, attributing such differences to the geographic location, nut genotype, soil and climate conditions (Aguilar Perez et al., 2015). Zinc is one of the most required nutrients for walnut trees, since its deficiency results in vein chlorosis, 
slow leaf growth and shortening of branches length, in addition that this mineral plays an important role as a chlorophyll stabilizer (Ojeda-Barrios et al., 2012). Besides, it is known that zinc consumption contributes to maintain important metabolic functioning in humans, such as protein and energy synthesis (Rose, 2016), and also as an anti-inflammatory agent (Jarosz et al., 2017); and its deficiency can delay growth and neuronal development, as well as immunity alterations and even death (Rubio et al., 2007). Zinc content in Criolla varieties can be considered as high, implying that Laguna region walnut trees requirements of this mineral are fulfilled, and that consumption of nut fruits from these Laguna Criolla varieties would promote health benefits for consumers.

Table 2. Mineral content $(\mathrm{mg} / 100 \mathrm{~g} \mathrm{dw})$ of pecan nut fruits from Criolla and Improved varieties grown in Laguna region (Durango, Mexico)

\begin{tabular}{|l|c|c|c|c|c|}
\hline \multicolumn{1}{|c|}{ Variety } & $\mathrm{Fe}$ & $\mathrm{Cu}$ & $\mathrm{Zn}$ & $\mathrm{Mn}$ & $\mathrm{Ca}$ \\
\hline 'Nazas I' & $58.5 \pm 4.2^{\mathrm{a}}$ & $12.5 \pm 1.4^{\mathrm{d}}$ & $59.6 \pm 4.4^{\mathrm{a}}$ & $27.4 \pm 2.3^{\mathrm{a}}$ & $131.4 \pm 13.2^{\mathrm{a}}$ \\
\hline 'Nazas II' & $35.7 \pm 3.3^{\mathrm{bc}}$ & $14.8 \pm 2.1^{\mathrm{c}}$ & $47.4 \pm 5.1^{\mathrm{b}}$ & $30.3 \pm 3.5^{\mathrm{a}}$ & $84.10 \pm 7.70^{\mathrm{b}}$ \\
\hline 'Norteña' & $23.2 \pm 3.7^{\mathrm{d}}$ & $16.7 \pm 2.0^{\mathrm{bc}}$ & $47.0 \pm 5.1^{\mathrm{b}}$ & $16.4 \pm 1.5^{\mathrm{b}}$ & $140.1 \pm 14.2^{\mathrm{a}}$ \\
\hline 'Wichita' & $29.9 \pm 3.2^{\mathrm{c}}$ & $18.1 \pm 1.8^{\mathrm{a}}$ & $38.1 \pm 3.9^{\mathrm{c}}$ & $7.11 \pm 1.0^{\mathrm{c}}$ & $102.5 \pm 9.80^{\mathrm{ab}}$ \\
\hline 'Western' & $36.8 \pm 4.1^{\mathrm{b}}$ & $17.0 \pm 2.9^{\mathrm{ab}}$ & $25.1 \pm 3.2^{\mathrm{d}}$ & $14.1 \pm 1.2^{\mathrm{b}}$ & $97.8 \pm 10.1^{\mathrm{ab}}$ \\
\hline
\end{tabular}

Results $(\mathrm{mg} / 100 \mathrm{~g} \mathrm{dw})$ stand for mean \pm standard deviation $(\mathrm{n}=5)$. Values in the same column followed by different character indicate significant difference according to the Fisher LSD test $\mathrm{P}<0.05$.

\section{Fatty acids profile}

One of the most important nutritional attributes of nut fruit is its high unsaturated fatty acids content, which are beneficial to human health (Atanasov et al., 2018). Results of fatty acids content in nut fruits of Criolla and Improved walnut varieties evaluated in this study indicate that oleic acid had the highest fatty acid content in all nut varieties, followed by the linoleic acid, and with low amounts palmitic, stearic and linolenic acid (Table 3). Pecan nut fruits from Criolla walnut varieties had higher oleic acid content (68-73\%), meanwhile Improved varieties had higher linoleic $(27.7 \pm 2.85 \%)$ and linolenic acid content $(1.51 \pm 0.15 \%$ in 'Wichita' variety). Regarding the saturated fatty acids, palmitic acid content was higher in Improved varieties, meanwhile stearic acid was similar in all nut varieties evaluated.

These results are similar to those reported in other studies, having Criolla nut varieties (Toro-Vazquez et al., 1999; Villarreal-Lozoya et al., 2007; Polmann et al., 2019) a higher oleic acid content than Improved varieties (Oro et al., 2008; Nishi et al., 2014). It has been proven that diets containing food products with a high oleic acid content are beneficial for health (Menendez et al., 2005; Carrillo et al., 2012), which is mostly due to its anti-lipidemic (Nishi et al., 2014, Dominguez-Avila et al., 2015), anti-inflammatory and anticarcinogenic properties (Banim et al., 2018). Therefore, ingest of nut fruits from these Criolla walnut varieties grown in La Laguna can promote health benefits for consumers.

Table 3. Fatty acid content (\%) of pecan nut oil of Criolla and Improved varieties cultivated in La Laguna (Mexico)

\begin{tabular}{|l|c|c|c|c|c|}
\hline \multicolumn{1}{|c|}{ Variety } & Palmitic & Stearic & Oleic & Linoleic & Linolenic \\
\hline 'Nazas I' & $4.15 \pm 0.52^{\mathrm{b}}$ & $2.57 \pm 0.36^{\mathrm{ab}}$ & $71.91 \pm 5.78^{\mathrm{a}}$ & $19.01 \pm 1.05^{\mathrm{cd}}$ & $1.38 \pm 0.18^{\mathrm{b}}$ \\
\hline 'Nazas II' & $4.57 \pm 0.45^{\mathrm{b}}$ & $2.87 \pm 0.27^{\mathrm{a}}$ & $73.01 \pm 8.64^{\mathrm{a}}$ & $17.37 \pm 1.36^{\mathrm{d}}$ & $1.25 \pm 0.15^{\mathrm{c}}$ \\
\hline 'Norteña' & $5.19 \pm 0.97^{\mathrm{b}}$ & $2.96 \pm 0.31^{\mathrm{a}}$ & $68.42 \pm 6.72^{\mathrm{b}}$ & $21.17 \pm 1.97^{\mathrm{c}}$ & $1.16 \pm 0.12^{\mathrm{c}}$ \\
\hline 'Western' & $6.19 \pm 0.65^{\mathrm{a}}$ & $2.48 \pm 0.25^{\mathrm{ab}}$ & $63.13 \pm 7.88^{\mathrm{c}}$ & $25.82 \pm 2.44^{\mathrm{b}}$ & $1.22 \pm 0.23^{\mathrm{c}}$ \\
\hline 'Wichita' & $7.23 \pm 0.71^{\mathrm{a}}$ & $1.95 \pm 0.17^{\mathrm{b}}$ & $58.32 \pm 5.94^{\mathrm{d}}$ & $29.64 \pm 3.25^{\mathrm{a}}$ & $1.51 \pm 0.18^{\mathrm{a}}$ \\
\hline
\end{tabular}

Results (\%) stand for mean \pm standard deviation $(n=5)$. Values in the same column followed by different character indicate significant difference according to the Fisher LSD test $\mathrm{P}<0.05$. 


\section{Antioxidant capacity}

Nut fruits contain phyto chemical compounds that could exert beneficial health effects due to their antioxidant properties (Villarreal-Lozoya et al., 2007; Laura et al., 2014). Antioxidant capacity of nut fruit oil from evaluated walnut varieties in this study (Figure 1) show that 'Norteña' variety (a Criolla variety) had 873.1 $\pm 78.8 \mu \mathrm{M}$ Trolox equivalent/g of oil, meanwhile 'Western' (an Improved variety) had 634.6 $\pm 61.1 \mu \mathrm{M}$ Trolox equivalent/g of oil; although there were not differences among all varieties (Table 3, p > 0.05).

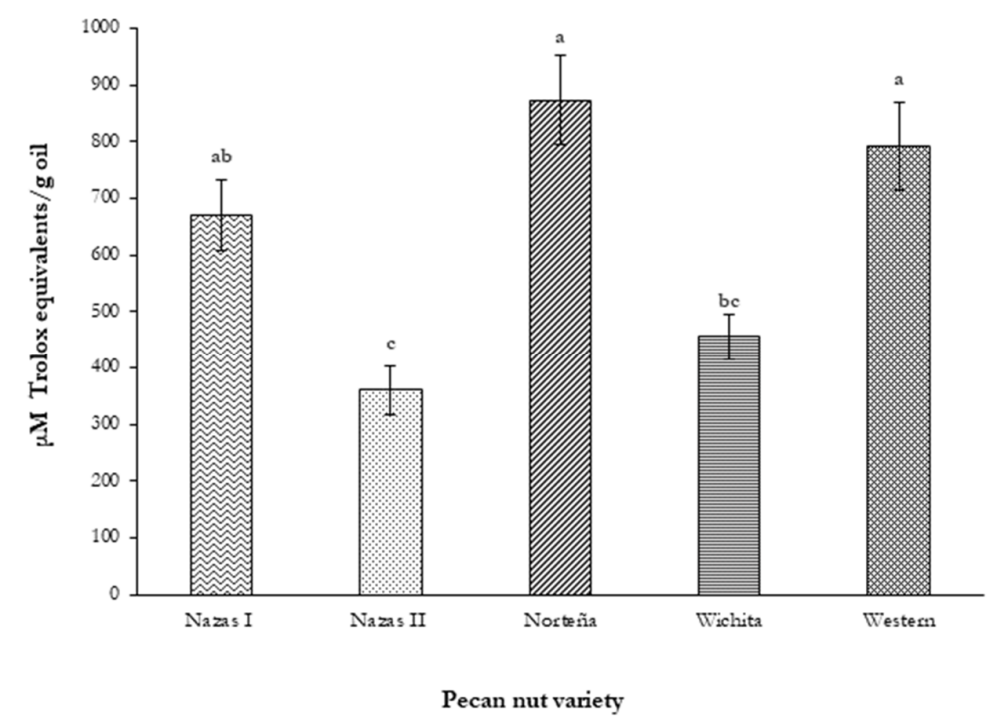

Figure 1. Antioxidant capacity ( $\mu \mathrm{M}$ Trolox equivalent/g of oil) in Criolla ('Nazas I', 'Nazas II' and 'Norteña') and Improved ('Wichita' and 'Western')

Column with different character indicate significant difference according to the Fisher LSD test $\mathrm{P}<0.05$.

The antioxidant capacity of nut oil is due to its unsaturated fatty acid composition as well as its vitamin E content, which are proven as excellent antioxidant agents (Jiang, 2014; Yang et al., 2015). There is not available literature regarding antioxidant capacity of oil nut, therefore these results could provide valuable information about antioxidant properties of oil nut from the Laguna walnut varieties evaluated in this study as good nutraceutical food product.

\section{Conclusions}

Pecan nut fruits of Criolla varieties cultivated in La Laguna have good nutrimental attributes and antioxidant capacity similar to those of Improved varieties such as 'Western' or 'Wichita'. Besides, Criolla varieties nut had a higher zinc, iron and oleic acid content than in Improved varieties evaluated. Hence, regular consumption of nut fruit of Criolla varieties can promote beneficial health effects to consumers.

\section{Authors' Contributions}

Methodology: NFCM; Funding acquisition: JGAA; Writing - review and editing: JRER, JRMF; Validation: ESC; Supervision and Writing - original draft: JAMV

All authors read and approved the final manuscript. 


\section{Acknowledgements}

This research received no specific grant from any funding agency in the public, commercial, or not-forprofit sectors.

\section{Conflict of Interests}

The authors declare that there are no conflicts of interest related to this article.

\section{References}

Aguilar Perez H, Arreola Avila J, Morales Olais E, Cuellar Villarreal E, Lagarda Murrieta A, Tarango Rivero H, ... Lombardini L (2015). Norteña Pecan. HortScience 50(9):1399-1400. https://doi.org/10.21273/HORTSCI.50.9.1399

Atanasov AG, Sabharanjak SM, Zengin G, Mollica A, Szostak A, Simirgiotis M... Mocan A (2018). Pecan nuts: A review of reported bioactivities and health effects. Trends in Food Science \& Technology 71:246-257. https://doi.org/10.1016/j.tifs.2017.10.019

Banim PJ, Luben R, Khaw K-T, Hart AR (2018). Dietary oleic acid is inversely associated with pancreatic cancer-Data from food diaries in a cohort study. Pancreatology 18(6):655-660. https://doi.org/10.1016/j.pan.2018.07.004

Beuchat L, Pegg R (2013). Improving the safety and quality of pecans. In: Improving the safety and quality of nuts. Elsevier, pp 297-329. https://doi.org/10.1533/9780857097484.2.297

Beuchat L, Worthington R (1978). Fatty acid composition of tree nut oils. International Journal of Food Science \& Technology 13(4):355-358. https://doi.org/10.1111/j.1365-2621.1978.tb00813.X

Bligh EG, Dyer WJ (1959). A rapid method of total lipid extraction and purification. Canadian Journal of Biochemistry and Physiology 37(8):911-917. https://doi.org/10.1139/o59-099

Carrillo C, Cavia M, Alonso-Torre S (2012). Antitumor effect of oleic acid; mechanisms of action. A review Nutrición Hospitalaria 27(5):1860-1865. http://dx.doi.org/10.3305/nh.2012.27.6.6010

Dominguez-Avila JA, Alvarez-Parrilla E, Lopez-Diaz JA, Maldonado-Mendoza IE, Gomez-Garcia M del C, de la Rosa LA (2015). The pecan nut (Carya illinoinensis) and its oil and polyphenolic fractions differentially modulate lipid metabolism and the antioxidant enzyme activities in rats fed high-fat diets. Food Chemistry 168:529-537. https://doi.org/10.1016/j.foodchem.2014.07.092

Duarte-Almeida JM, Santos RJd, Genovese MI, Lajolo FM (2006). Avaliação da atividade antioxidante utilizando sistema beta-caroteno/ácido linoléico e método de seqüestro de radicais DPPH. Food Science and Technology 26 (2):446-452. https://doi.org/10.1590/S0101-20612006000200031

Grauke LJ (1988). Pecan germplasm repository expands with collection from native Mexican populations. Pecan South, vol 22.

Horwitz W (2010). Official methods of analysis of AOAC International. Volume I, agricultural chemicals, contaminants, drugs. Ed Horwitz W. Gaithersburg (Maryland): AOAC International, 1997.

Jarosz M, Olbert M, Wyszogrodzka G, Młyniec K, Librowski T (2017). Antioxidant and anti-inflammatory effects of zinc. Zinc-dependent NF- $\kappa B$ signaling. Inflammopharmacology 25(1):11-24. https://doi.org/10.1007/s10787017-0309-4

Jiang Q (2014). Natural forms of vitamin E: metabolism, antioxidant, and anti-inflammatory activities and their role in disease prevention and therapy. Free Radical Biology and Medicine 72:76-90. http://doi.org/10.1016/j.freeradbiomed.2014.03.035

Vazquez-Flores LA, Alvarez-Parrilla E, Rodrigo-García J, Medina-Campos ON, Ávila-Nava A, González-Reyes S, Pedraza- AA Chaverri J (2014). Content of major classes of polyphenolic compounds, antioxidant, antiproliferative, and cell protective activity of pecan crude extracts and their fractions. Journal of Functional Foods 7:219-228. https://doi.org/10.1016/j.jff.2014.02.008

Martínez-Peniche RA (2001). Nut quality of native pecan selections [Carya illinoensis (Wangenh) K. Koch) in central México. Acta Horticulturae 565:69-73. https://doi.org/10.17660/ActaHortic.2001.565.10 
Menendez J, Vellon L, Colomer R, Lupu R (2005). Oleic acid, the main monounsaturated fatty acid of olive oil, suppresses her-2/neu (erb b-2) expression and synergistically enhances the growth inhibitory effects of trastuzumab $\left(\right.$ herceptin ${ }^{\text {Tx }}$ ) in breast cancer cells with her-2/neu oncogene amplification. Annals of Oncology 16(3):359-371. https://doi.org/10.1093/annonc/mdi090

Mudgil D, Barak S (2013). Composition, properties and health benefits of indigestible carbohydrate polymers as dietary fiber: a review. International Journal of Biological Macromolecules 61:1-6. https://doi.org/10.1016/j.ijbiomac.2013.06.044

Nishi S, Kendall C, Bazinet R, Bashyam B, Ireland C, Augustin L... Jenkins D (2014). Nut consumption, serum fatty acid profile and estimated coronary heart disease risk in type 2 diabetes. Nutrition, Metabolism and Cardiovascular Diseases 24(8):845-852. https://doi.org/10.1016/j.numecd.2014.04.001

Ojeda-Barrios D, Abadía J, Lombardini L, Abadía A, Vázquez S (2012). Zinc deficiency in field-grown pecan trees: changes in leaf nutrient concentrations and structure. Journal of the Science of Food and Agriculture 92(8):1672-1678. https://doi.org/10.1002/jsfa.5530

Oro T, Ogliari PJ, Amboni R, Barrera-Arellano D, Block JM (2008). Evaluación de la calidad durante el almacenamiento de nueces Pecán [Carya illinoinensis (Wangenh.) C. Koch] acondicionadas en diferentes envases. Grasas y Aceites 59(02):132-138. https://doi.org/10.3989/gya.2008.v59.i2.501

Ötles S, Ozgoz S (2014). Health effects of dietary fiber. Acta Scientiarum Polonorum Technologia Alimentaria 13(2):191-202. https://doi.org/10.1111/j.1753-4887.2009.00189.x

Ozkan G, Koyuncu MA (2005). Physical and chemical composition of some walnut (Juglans regia L) genotypes grown in Turkey. Grasas y Aceites 56(2):141-146. https://doi.org/10.3989/gya.2005.v56.i2.122

Polmann G, Badia V, Frena M, Teixeira GL, Rigo E, Block JM, Feltes MMC (2019). Enzyme-assisted aqueous extraction combined with experimental designs allows the obtaining of a high-quality and yield pecan nut oil. LWT:108283. https://doi.org/10.1016/j.lwt.2019.108283

Rose J (2016). Trace elements in health: a review of current issues. Butterworth-Heinemann. https://www.ncbi.nlm.nih.gov/sars-cov-2/

Rubio C, González Weller D, Martín-Izquierdo R, Revert C, Rodríguez I, Hardisson A (2007). El zinc: oligoelemento esencial. Nutrición Hospitalaria 22(1):101-107. http://scielo.isciii.es

Santerre CR (1994). Pecan composition. In: Pecan Technology. Springer, pp 98-110. https://doi.org/10.1007/978-14615-2385-7_7

Senter S, Horvat R (1978). Minor fatty acids from pecan kernel lipids. Journal of Food Science 43(5):1414-1415. https://doi.org/10.1111/j.1365-2621.1978.tb02506.x

SIAP-SAGARPA (2018). Servicio de Información Agroalimentaria y Pesquera-Secretaría de Agricultura, Ganadería, Desarrollo Rural, Pesca y Alimentación. https://nube.siap.gob.mx

Singanusong R, Mason RL, D’Arcy BR, Nottingham SM (2003). Compositional changes of Australia-grown Western Schley pecans [Carya illinoinensis (Wangenh.) K. Koch] during maturation. Journal of agricultural and food chemistry 51(2):406-412. http://doi.org/10.1021/jf025869a

Su M, Venkatachalam M, Teuber SS, Roux KH, Sathe SK (2004). Impact of $\gamma$-irradiation and thermal processing on the antigenicity of almond, cashew nut and walnut proteins. Journal of the Science of Food and Agriculture 84(10):1119-1125. https://doi.org/10.1002/jsfa.1748

Thompson TE, Grauke L (2012). Lipan Pecan. HortScience 47(1):121-123. https://doi.org/10.21273/HORTSCI.47.1.121

Toro-Vazquez J, Charó-Alonso M, Pérez-Briceño F (1999). Fatty acid composition and its relationship with physicochemical properties of pecan (Carya illinoensis) oil. Journal of the American Oil Chemists' Society 76(8):957-965.

Villarreal-Lozoya JE, Lombardini L, Cisneros-Zevallos L (2007). Phytochemical constituents and antioxidant capacity of different pecan [Carya illinoinensis (Wangenh.) K. Koch] cultivars. Food Chemistry 102(4):1241-1249. https://doi.org/10.1016/j.foodchem.2006.07.024

Wakeling LT, Mason RL, D’Arc BR, Caffin NA (2001). Composition of pecan cultivars Wichita and Western Schley [Carya illinoinensis (Wangenh.) K. Koch] grown in Australia. Journal of Agricultural and Food Chemistry 49(3):1277-1281. http://doi.org/10.1021/jf000797d

Yang J, Zhou F, Xiong L, Mao S, Hu Y, Lu B (2015). Comparison of phenolic compounds, tocopherols, phytosterols and antioxidant potential in Zhejiang pecan [Carya cathayensis] at different stir-frying steps. LWT-Food Science and Technology 62(1):541-548. https://doi.org/10.1016/j./wt.2014.09.049 
OPEN ACCESS

(c) (i)

The journal offers free, immediate, and unrestricted access to peer-reviewed research and scholarly work. Users are allowed to read, download, copy, distribute, print, search, or link to the full texts of the articles, or use them for any other lawful purpose, without asking prior permission from the publisher or the author.

License - Articles published in Notulae Botanicae Horti Agrobotanici Cluj-Napoca are Open-Access, distributed under the terms and conditions of the Creative Commons Attribution (CC BY 4.0) License.

(c) Articles by the authors; UASVM, Cluj-Napoca, Romania. The journal allows the author(s) to hold the copyright/to retain publishing rights without restriction. 